Journal of Applied Veterinary Sciences, 7 (1): 1-5 (January, 2022).

ISSN: Online: 2090-3308, Print: 1687-4072

Journal homepage : https://javs.journals.ekb.eg

\title{
The Roles of Apigenin Cream on Wound Healing in Rabbits Model
}

\author{
Ammar M. Rajab ${ }^{1}$, Wael T. Al-Wattar ${ }^{2}$ and Ghada A. Taqa ${ }^{3}$ \\ ${ }^{1}$ Ministry of Health, Nineveh Health Directorate, Mosul, Iraq. \\ ${ }^{2}$ Department of Oral and Maxillofacial Surgery, College of Dentistry, University of Mosul, Mosul, Iraq. \\ ${ }^{3}$ Department of Dental Basic Science, College of Dentistry, University of Mosul, Mosul, Iraq. \\ a) *Corresponding Author: Ammar M. Rajab, E-Mail: ammar.dep4@ student.uomosul.edu.iq
}

\begin{abstract}
This study aims to evaluate the healing effect of topical Apigenin cream 2\% in the skin of rabbits. Twenty Four healthy Newzealand adult male rabbits approximately at the same age were involved in this study. All animals were anesthetized using a mixture of $40 \mathrm{mg} / \mathrm{kg}$ ketamine injection and xylazine 4 $\mathrm{mg} / \mathrm{kg}$ intramuscularly. The skin of the dorsum area of each rabbit was shaved; then, three incisions $(1 \mathrm{~cm}$ in length) were made. Wounds were left without suturing to heal by secondary intention healing, and each animal had three wounds (wounds divided into three groups according to the type of treatment): one treated with Apigenin cream twice a day, the other with cold cream twice a day, and the third wound was left untreated. The application of cream was repeated daily; the wound size and the ratio of wound contraction were assessed at the first, fourth, and seventh days of study. The results revealed that the group treated with apigenin showed significantly better wound healing capacity in the skin of rabbits; wound size and wound contraction ratio was superior in the Apigenin group compared to control positive and negative groups. It can be concluded that apigenin cream has beneficial value for improving the wound healing potential of skin in rabbits.
\end{abstract}

Original Article:

DOI:https://dx.doi.org/10.21608/javs.2 021.97151.1104

Received :20 September, 2021. Accepted:02 November, 2021. Published in January, 2022.

This is an open access article under the term the Creative Commons Attribution 4.0 (C BY) International License . To view a copy this license, visit:

http://creativecommons.org/licenses/by/4.0/

J. Appl. Vet. Sci., 7 (1 ): 1-5.

Keywords: Apigenin, Wound contraction ratio, Wound healing, Wound size.

\section{INTRODUCTION}

A wound is a breakdown in the skin's protective function; the destruction of epithelium continuity, with or without destruction of underlying connective tissue (bone, muscle, and nerves), following damage to the skin or underlying tissues caused by surgery, a cut, heat/cold, chemicals, pressure, friction, or diseases, such as carcinomas or leg ulcers (Shankar et al., 2014). Any damage or break in the skin initiates a series of events that culminate in the migration of specialized cells into the wound site to heal the wound (Khunger, 2017). Wound healing is a complicated process that requires various cells, growth factors, cytokines, and extracellular matrix (ECM) (Martin and Nunan, 2015).

Wound healing is a crucial physiological process for maintaining skin integrity. Normal wound healing consists of four sequential but overlapping phases: hemostasis, inflammatory phase, proliferative phase, and remodeling phase (Wang et al., 2018). The fundamental aim of topical wound care is to restore structural and morphological features of the skin, which is required to avoid external environment infections, keep wounds moist, and maintain internal environment homeostasis. This reduces edema and increases blood flow, saving time and money while improving quality of life. (Hunckler and De Mel, 2017; Khunger, 2017).

Apigenin has many biological properties of naturally occurring flavonoids, such as antithrombotic, hepatoprotective, antiviral, and anti-inflammatory activities. Many of them are thought to be related (at least in part) to their antioxidant and free radical scavenging properties (Rehecho et al., 2011).

Apigenin, which is found in many plants, including chamomile, has been shown to function as a natural anti-inflammatory agent (Durate et al., 2011). Its effectiveness in treating symptoms of gastritis, gastric ulcers, and other mucosal inflammatory diseases is attributed to the presence of apigenin glycosides in the plant. Recent research suggests that apigenin may be useful in treating skin inflammation caused by free radicals (Lopez Jornet et al., 2014). 


\section{The roles of Apigenin cream on Wound Healing ......}

Consequently, this research aims to investigate the healing capacity of topical apigenin cream $2 \%$ on wound healing in rabbit skin.

\section{MATERIALS AND METHODS}

\section{Animals:}

The experiment randomly allocated 24 New Zealand adult male rabbits aged about 5-7 months, weighing $1.5-2 \mathrm{~kg}$. The animals were kept in the animal's house of Collage of Dentistry, University of Mosul, Mosul, Iraq.

\section{Preparation of Apigenin cream:}

Apigenin powder has been bought from (Yanhuang Industrial Park, Guanxian, Liaocheng, Shandong, China). Apigenin cream is prepared by mixing pure apigenin powder with cold cream (beeswax, paraffin oil, borax and purified water) in measured doses of cream and apigenin powder, $2 \mathrm{gm}$. apigenin powder, and $98 \mathrm{gm}$. cold cream for obtaining $2 \%$ apigenin cream. The apigenin cream was stored in special containers and stored in a dry cooled environment (refrigerator at $4 \mathrm{C}^{\circ}$ ) to be used later in this study. The same cold cream was used as control positive in the study.

\section{Trial on animals:}

Twenty-four rabbits participated in this study. Each rabbit received a $40 \mathrm{mg} / \mathrm{kg}$ ketamine injection intramuscularly in the thigh muscle, combined with 4 $\mathrm{mg} / \mathrm{kg}$ of xylazine of rabbit weight (Ahirwar et al., 2021). The rabbit's weight was recorded using electronic digital scales, and the rabbit's reflexes were checked after 5-10 minutes to confirm that anesthesia was properly administered.

Animals in all groups were prepared aseptically. A full-thickness longitudinal skin incision was made, and the defect was $1 \mathrm{~cm}$ in length. All the Defective wounds left without suturing to heal by secondary intentional healing.

Three stab incisions were made at the dorsum area through the skin of each rabbit. The first incision treated with apigenin cream $2 \%$, the second incision treated with cold cream alone, and the last incision left without treatment. Wounds were divided randomly into three experimental groups; each group consisted of twenty-four wounds according to the treatment material used.

G1: (Apigenin group): 24 wounds treated with topical apigenin $2 \%$ cream twice daily.

G2: (Control positive group): 24 wounds treated with topical cold cream alone two times daily.

G3: (Control negative group): 24 wounds did not receive any treatment.

The application of apigenin and cold cream was repeated twice daily. The wounds were totally covered with cream for 7 days. The wound measurement was carried out on the $1^{\text {st }}, 4^{\text {th }}$, and $7^{\text {th }}$ Days of the experiment.

Vernia device was used to calculate the changes in wound size in $\mathrm{mm}^{2}$ by multiplying the longest and widest measurement in the wound bed in millimeters. Percentage of wound Contraction ratio (WCR) was calculated taking the initial size of the wound as 100\% using the following formula: (Taqa $\boldsymbol{e t}$ al., 2014; Nagar et al., 2016)

$$
\mathrm{WCR}=\frac{\text { Initial wound area }- \text { Specific day wound area })}{\text { Initial } \text { wound area }} \times 100
$$

\section{Statistical analysis:}

The data were collected to find the means and standard deviation of each group. These data were used to analyze the difference between groups by using oneway analysis of variance (ANOVA) with Duncan Multiple Analysis Rang Test, $\mathrm{p} \leq 0.05$ has relied as significance value.

\section{RESULTS}

In the present research, one day postoperatively, the value of the wound size mean was $26.66 \mathrm{~mm}^{2}$ and the wound contraction ratio was 11.11 $\%$ in the positive control group. In contrast, the control negative wound size mean was $27 \mathrm{~mm}^{2}$ and the wound contraction ratio was $10 \%$ which was the lowest value on this day of study; the wound size mean of apigenin $2 \%$ group was $24 \mathrm{~mm}^{2}$ with wound contraction ratio equals $20 \%$ which was the best healing score between all groups. But there was no significant difference between all groups at $\mathrm{p}$-value $\leq 0.05$ (Table 1,2 and Figs. 1,2).

Table 1: Wound size findings of skin comparing between control positive, control negative and apigenin groups:

\begin{tabular}{|c|c|c|c|}
\hline Duration & Group & $\begin{array}{l}\text { Wound size } \\
(\text { Mean + SD) }\end{array}$ & $\begin{array}{l}\mathrm{P} \\
\text { valu } \\
\mathrm{e}\end{array}$ \\
\hline \multirow{3}{*}{$1^{\text {st }}$ Day } & Control positive & $26.666 \pm 4.618$ & \multirow{3}{*}{0.002} \\
\hline & Control negative & $27.000 \pm 0.00$ & \\
\hline & Apigenin $2 \%$ & $24.000 \pm 0.00$ & \\
\hline \multirow{3}{*}{$4^{\text {th }}$ day } & Control positive & $24.3333 \pm 3.511$ & \multirow{3}{*}{0.001} \\
\hline & Control negative & $26.6667 \pm 4.618$ & \\
\hline & Apigenin $2 \%$ & $12.6667 \pm 4.041$ & \\
\hline \multirow{3}{*}{$7^{\text {th }}$ day } & Control positive & $14.3333 \pm 4.041$ & \multirow{3}{*}{0.004} \\
\hline & Control negative & $17.0000 \pm 4.582$ & \\
\hline & Apigenin $2 \%$ & $7.3333 \pm 1.154$ & \\
\hline
\end{tabular}


Ammar M. Rajab, et al.........

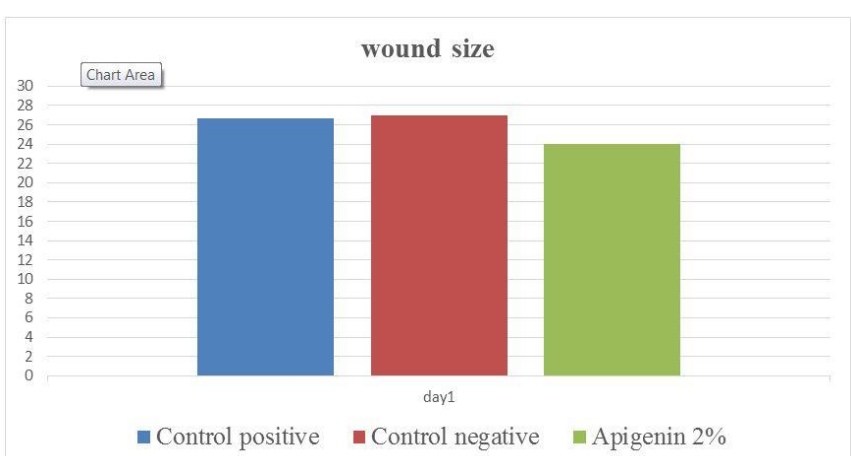

Fig. 1: Mean rank deference of skin wound size between groups treated topically on the first day.

Table 2: Apigenin cream effect on Wound contraction ratio in comparison to control groups.

Wound contraction ratio

\begin{tabular}{lccc}
\hline group & Day 1 & Day3 & Day7 \\
\hline $\begin{array}{l}\text { Control } \\
\text { positive }\end{array}$ & $11.11 \%$ & $18.9 \%$ & $52.23 \%$ \\
\hline $\begin{array}{l}\text { Control } \\
\text { negative }\end{array}$ & $10 \%$ & $11.13 \%$ & $43.33 \%$ \\
\hline Apigenin $2 \%$ & $20 \%$ & $57.8 \%$ & $75.56 \%$ \\
\hline
\end{tabular}

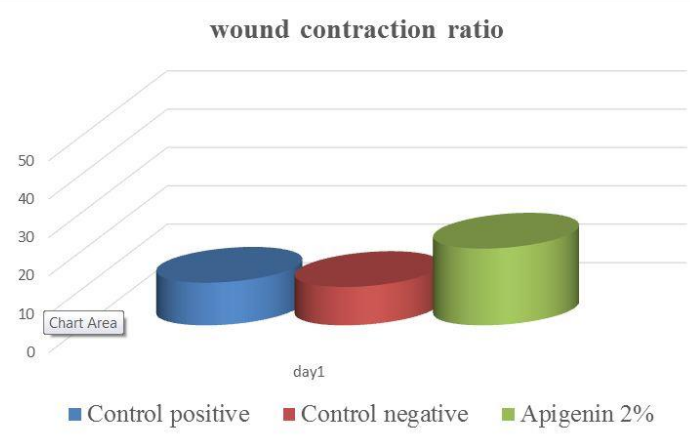

Fig. 2: Effect of apigenin 2\% cream on wound contraction ratio in rabbits after the first day.

On Day Four of this study, the value of the wound size mean was $24.33 \mathrm{~mm}^{2}$, and the wound contraction ratio was $18.9 \%$ in the positive control group, while in the negative control group; the value of wound size mean $26.66 \mathrm{~mm}^{2}$ with wound contraction ratio $11.13 \%$, apigenin group also maintained the best result between groups, with contraction ratio $57.8 \%$ and mean value of wound size $12.66 \mathrm{~mm}^{2}$.

Apigenin group showed a significant difference in comparison to control groups at a p-value $\leq$ of 0.05 . It was found that the control positive and control negative groups had similar values. (Table 1,2 and Figs. 3,4).

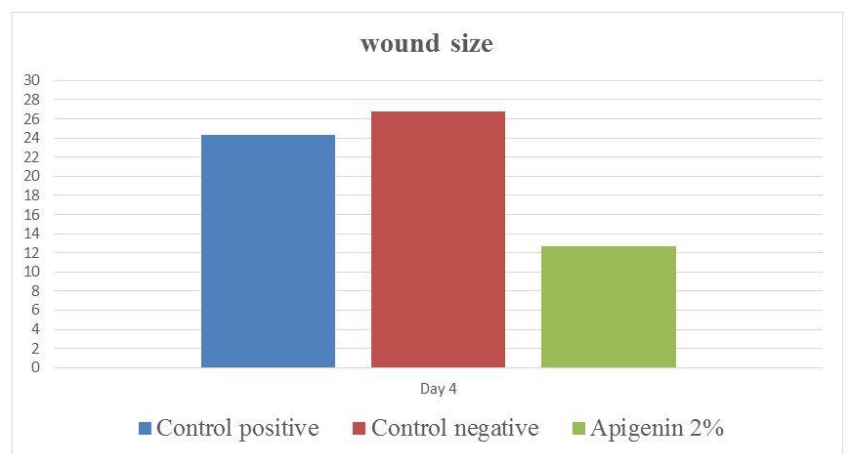

Fig. 3: Mean rank deference of skin wound size between groups treated topically on the fourth day.

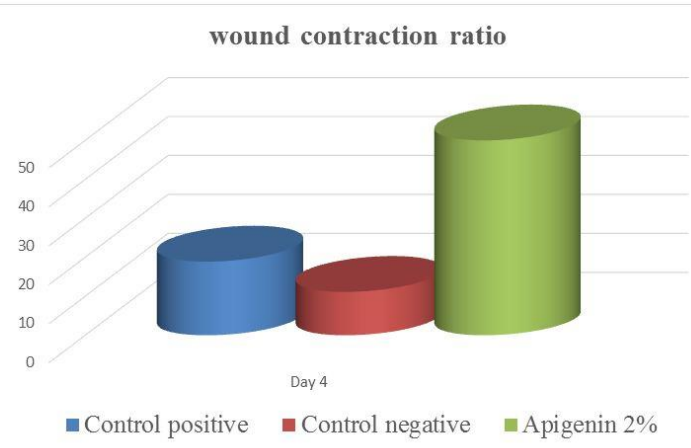

Fig. 4: Effect of apigenin 2\% cream on wound contraction ratio in rabbits after four days.

On Day seven of the study, the wound size mean values were measured and the wound size for the positive control group was $14.33 \mathrm{~mm}^{2}$. The wound contraction ratio was $52.23 \%$. The control positive wound size was $17 \mathrm{~mm}^{2}$ with a wound contraction ratio of $43.33 \%$. In the apigenin group, the healing score was also the best among all groups. The wound size mean was $7.33 \mathrm{~mm}^{2}$ and the wound contraction ratio 75.56 $\%$.

There was a significant difference between the groups treated with apigenin and control groups, whereas there was no significant difference between control positive and control negative groups(Table 1,2 and Figs.5,6).

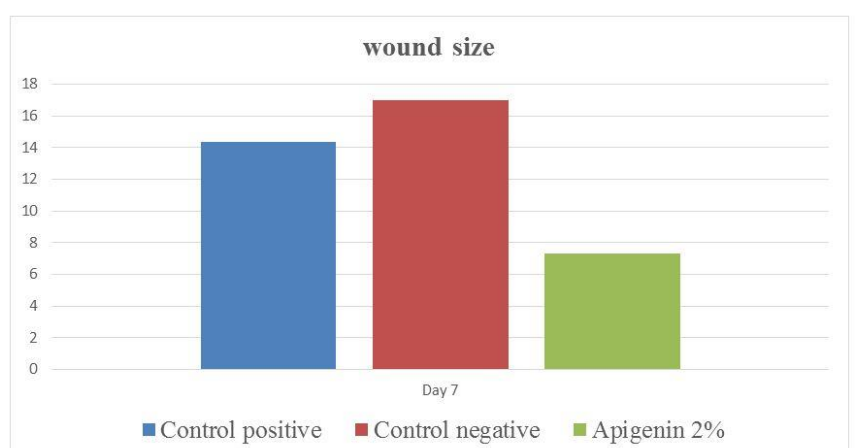

Fig. 5: Mean rank deference of skin wound size between groups treated topically on the seventh day. 


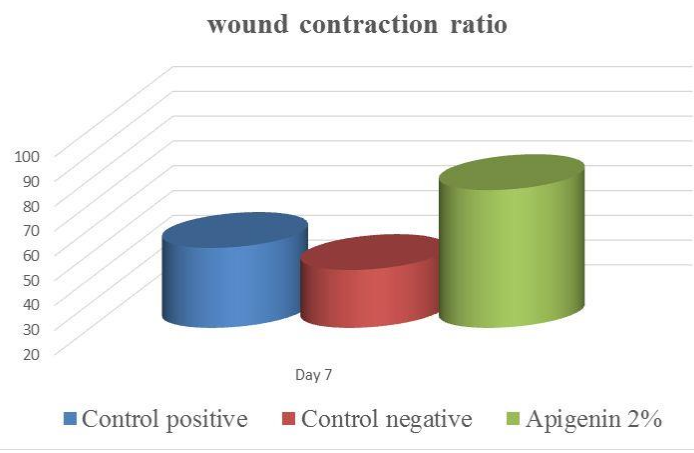

Fig. 6: Effect of apigenin 2\% cream on wound contraction ratio in rabbits after seven days.

\section{DISCUSSION}

Wound healing is a complicated and dynamic process involving replacing devitalized and lost cellular components and tissue layers. There are four overlapping phases of wound healing: hemostasis, inflammatory phase, proliferative phase, and remodeling phase. These stages occur sequentially as a result of the integration of dynamic processes, including cellular mediators, blood cells, and parenchymal cells (Strodtbeck, 2001; Gonzalez et al., 2016; Sorg et al., 2017).

As a primary indicator of healing, wound size assessment may provide an effective treatment protocol, provide an objective form of analysis, anticipate healing, improve quality of care, contribute to more accurate professional communication, and improve wound management (Humbert et al., 2004; Williams et al., 2017).

In our study, apigenin significantly improved wound healing after the fourth and seventh days in comparison to other groups in this study, this effect of apigenin on wound healing may return to many pharmacological effects of apigenin; apigenin may enhance the re-epithelialization process and collagen fiber deposition in the dermis, as well as the efficiency of granulation tissue formation (Motealleh et al., 2014).

Another apigenin function is that it has an antiinflammatory and chemo-preventive impact; apigenin directly reduced $(\mathrm{Src})$ activity. Src (a non-receptor tyrosine kinase) is an oncogenic kinase whose activity is connected to inflammatory reactions, apigenin directly bind to src leading to Src inhibition and decreased inflammatory changes; Src inhibition is thought to be an important factor for avoiding inflammation and cancer because it suppresses downstream signaling pathways to decrease COX-2 expression which is implicated in skin inflammation and carcinogenesis (Byun et al., 2013).
Apigenin inhibits acute inflammation by improving epidermal permeability barrier function, and topical apigenin partly inhibits changes in stratum corneum hydration and skin surface $\mathrm{pH}$ by lowering transepidermal water loss, which could be attributed to apigenin's anti-inflammatory and antioxidant properties (Man et al., 2012).

Apigenin also suppresses the production of inflammation-related molecules produced by TNFalpha and IL-1alpha, such as intercellular adhesion molecule-1, vascular cell adhesion molecule-1, and Eselectin (Lim and Kim., 2007).

Some researchers believe that apigenin inhibits inflammation by decreasing matrix metalloproteinase- 1 expression and inhibiting the proinflammatory cytokines TNF- alpha and IL-6 at very low micromole levels via inhibiting NF- $\kappa \mathrm{B}$ activation and phosphorylation of p38 and JNK in macrophages antioxidants (Man et al., 2012; Xie et al., 2012), As well as its positive role in activating the factor Nuclear Factor Erythroid 2-Related (NrF-2) that regulates the process of cloning the genes responsible for the manufacture of antioxidant enzymes like glutathione ( Ibrahim et al., 2020).

Trauma illnesses have oxidative stress as an important part of their pathophysiology. After tissue damage, reactive oxygen species (ROS) production frequently increases in the wounded cells. Antioxidant biomaterials could effectively prevent ROS damage to cells so that they promote wound healing (Liu et al., 2018; Ibrahim et al., 2020). Many previous studies established the antioxidant effects of apigenin so that we could attribute the enhanced wound healing in the apigenin group to their antioxidant properties (Huang et al., 2019; Xu et al., 2020).

Apigenin has a well known antioxidant effect. According to several studies, antioxidants suppress the production of inflammatory mediators such as leukotrienes, histamine, IL-8, IL-6, and TNF from mast cells. As a result, It is possible that the antioxidant properties of apigenin are responsible for its antiinflammatory effects. (Weng et al., 2012).

Apigenin's lipid peroxidation inhibition effect is thought to improve collagen fibril viability by stimulating DNA synthesis and minimizing cell damage resulting in enhanced wound healing in the proliferation phase, with increased blood vessels, collagen fibers, and fibroblast cell growth in wounds treated with apigenin (Lopez Jornet et al., 2014; Shukla et al., 2016). 


\section{CONCLUSION}

The data analysis of this study revealed a positive effect of apigenin in the acceleration of wound healing in rabbits.

\section{Declaration of Conflicting Interests}

The authors revealed that there is no potential conflicts of interest.

\section{REFERENCES}

AHIRWAR, L.K., KALRA, P., SHARMA, S., MOHAMED, A., MITTAL, R., DAS, S., and BAGGA, B., 2021. Linezolid shows high safety and efficacy in the treatment of Pythium insidiosum keratitis in a rabbit model. Experimental Eye Research, 202, p.108345. https://doi.org/10.1016/j.exer.2020.108345

BYUN, S., PARK, J., LEE, E., LIM, S., YU, J.G., LEE, S.J., CHEN, H., DONG, Z., LEE, K.W., and LEE, H.J., 2013. Src kinase is a direct target of apigenin against UVB-induced skin inflammation . Carcinogenesis, 34(2), pp.397-405. https://doi.org/10.1093/carcin/bgs358

DUARTE, C.M.E., QUIRINO, M.R.S., PATROCÍNIO, M.C., and ANBINDER, A.L., 2011. Effects of Chamomilla recutita (L.) on oral wound healing in rats. 16:716-721.http://hdl.handle.net/10550/60099

GONZALEZ, A.C.D.O., COSTA, T.F., ANDRADE, Z.D.A., and MEDRADO, A.R.A.P., 2016. Wound healing-A literature review. Anais brasileiros de dermatologia, 91, pp.614-620. https://doi.org/10.1590/abd1806-4841.20164741

HUANG, J., CHEN, L., GU, Z., and WU, J., 2019. Red jujube-incorporated gelatin methacryloyl (GelMA) hydrogels with anti-oxidation and immunoregulation activity for wound healing. J. Biomed. Nanotechnol, 15, pp.1357-1370. https://doi.org/10.1166/jbn.2019.2815

HUMBERT, P., MEAUNE, S., and GHARBI, T., 2004. Wound healing assessment. Phlebolymphology, 47, pp.312-319.https://www.phlebolymphology.org/woundhealing-assessment/

HUNCKLER, J., and DE MEL, A., 2017. A current affair: electrotherapy in wound healing. Journal of multidisciplinary healthcare, 10, p.179. https://dx.doi.org/10.2147\%2FJMDH.S127207

IBRAHIM, R.T.I., MAHMMOD, A.A.M., and TAQA, G.A.R.T., 2020. Synthesis of Silver Nanoparticles Using Catechin and Apigenin and Study their Antioxidant Effect on the Laboratory Rats. College Of Basic Education Researches Journal, 16(3), pp.919943.https://berj.mosuljournals.com/?_action=article\&ke ywords $=$ Synthesis + of + Silver+Nano+particles

KHUNGER, N. 2017. Accelerated wound healing: Harnessing the power of platelets, biomaterials, stem cells and gene therapy. Journal of cutaneous and aesthetic surgery, 10(1),p.1.

https://dx.doi.org/10.4103\%2FJCAS.JCAS $32 \quad 17$

LIM, H., and KIM, H.P., 2007. Inhibition of mammalian collagenase, matrix metalloproteinase-1, by naturally occurring flavonoids. Planta Medica, 73(12), pp.12671274.https://doi.org/10.1055/s-2007-990220
LIU, J., CHEN, Z., WANG, J., LI, R., LI, T., CHANG, M., YAN, F., and WANG, Y., 2018. Encapsulation of curcumin nanoparticles with MMP9-responsive and thermos-sensitive hydrogel improves diabetic wound healing. ACS applied materials \& interfaces, 10(19), pp.16315-16326.https://doi.org/10.1021/acsami.8b03868

LOPEZ-JORNET, P., CAMACHO-ALONSO, F., GÓMEZ-GARCIA, F., MOLINA MINANO, F., CAÑAS, X., SERAFín, A., CASTILlO, J., and VICENTE-ORTEGA, V., 2014. Effects of potassium apigenin and verbena extract on the wound healing process of SKH-1 mouse skin. International wound Journal, 11(5), pp.489-495. https://doi.org/10.1111/j.1742-481X.2012.01114.x

MAN, M.Q., HUPE, M., SUN, R., MAN, G., MAURO, T.M., and ELIAS, P.M., 2012. Topical apigenin alleviates cutaneous inflammation in murine models. Evidence-Based Complementary and Alternative Medicine https://doi.org/10.1155/2012/912028

MARTIN, P., and NUNAN, R., 2015. Cellular and molecular mechanisms of repair in acute and chronic wound healing. British Journal of Dermatology, 173(2), pp.370-378. https://doi.org/10.1111/bjd.13954

MOTEALLEH, B., ZAHEDI, P., REZAEIAN, I., MOGHIMI, M., ABDOLGHAFFARI, A.H., and ZARANDI, M.A., 2014. Morphology, drug release, antibacterial, cell proliferation, and histology studies of chamomile-loaded wound dressing mats based on electrospun nanofibrous poly ( $\varepsilon$-caprolactone)/ polystyrene blends. Journal of Biomedical Materials Research Part B: Applied Biomaterials, 102(5), pp.977987. https://doi.org/10.1002/jbm.b.33078

NAGAR, H.K., SRIVASTAVA, A.K., SRIVASTAVA, R., KURMI, M.L., CHANDEL, H.S., and RANAWAT, M.S., 2016. Pharmacological investigation of the wound healing activity of Cestrum nocturnum (L.) ointment in Wistar albino rats. Journal of Pharmaceutics, 1-8. https://doi.org/10.1155/2016/9249040

REHECHO, S., HIDALGO, O., DE CIRANO, M.G.I., NAVARRO, I., ASTIASARÁN, I., ANSORENA, D., CAVERO, R.Y., and CALVO, M.I., 2011. Chemical composition, mineral content and antioxidant activity of Verbena officinalis L. LWT-Food Science and Technology, 44(4), pp.875-882. https://doi.org/10.1016/j.lwt.2010.11.035

SHANKAR, M., RAMESH, B., KUMAR, D.R., and NIRANJAN, B.M., 2014. Wound healing and its importance-a review. Der Pharmacologia Sinica, 1(1), pp.24-30.https://www.researchgate.net/publication/318877193

How to cite this article:

Ammar M. Rajab, Wael T. Al-Wattar and Ghada A. Taqa, 2022. The Roles of Apigenin Cream on Wound Healing in Rabbits Model. Journal of Applied Veterinary Sciences, 7 (1): $01-05$. DOI: https://dx.doi.org/10.21608/javs.2021.97151.1104 